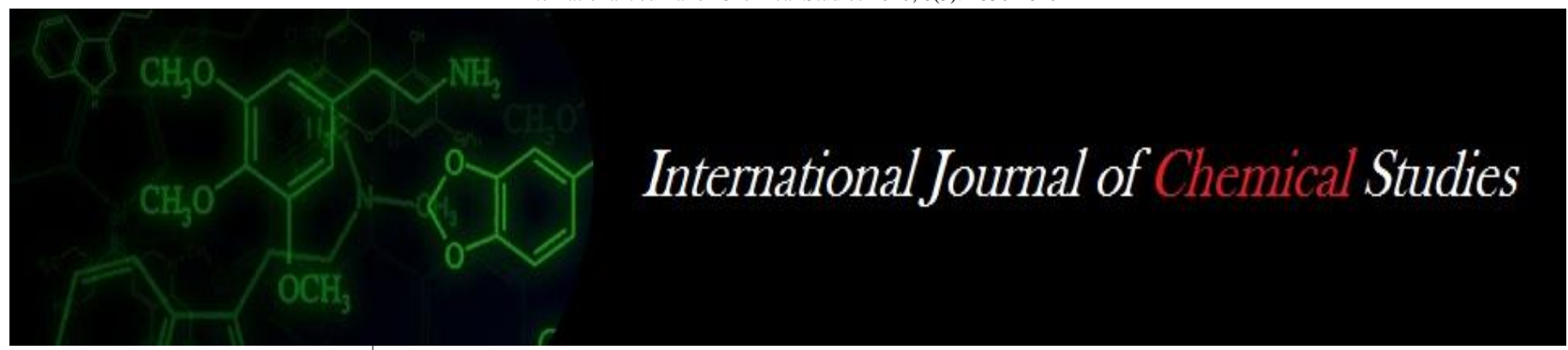

P-ISSN: 2349-8528

E-ISSN: 2321-4902

www.chemijournal.com

IJCS 2020; 8(5): 1836-1840

(C) 2020 IJCS

Received: 21-06-2020

Accepted: 19-08-2020

Thorave DS

Ph.D. Students, Department of Agronomy, N.M. College of Agriculture, Navsari, Navsari Agricultural University, Navsari, Gujarat, India

\section{Thanki JD}

Professor and Head, Department of Agronomy, N.M. College of Agriculture, Navsari, Navsari Agricultural University, Navsari, Gujarat, India

\section{Patil KB}

Ph.D. Students, Department of Agronomy, N.M. College of Agriculture, Navsari, Navsari Agricultural University, Navsari, Gujarat, India
Corresponding Author:

Thorave DS

N.M. College of Agriculture,

Navsari, Navsari Agricultural

University, Navsari, Gujarat,

India

\section{Response of inter and intra row spacing of sugarcane by using single eye bud settling on nutrient content, uptake and soil fertility status after harvest of sugarcane}

\author{
Thorave DS, Thanki JD and Patil KB
}

DOI: https://doi.org/10.22271/chemi.2020.v8.i5y.10568

\begin{abstract}
A field experiment was conducted in clay soil in texture, low in organic carbon $(0.27$ and $0.32 \%)$, low in available nitrogen (210 and $204 \mathrm{~kg} / \mathrm{ha}$ ), medium in available phosphorus (24 and $29 \mathrm{~kg} / \mathrm{ha})$, high in available potassium (281 and $289 \mathrm{~kg} / \mathrm{ha}$ ) and slightly alkaline in reaction (pH 7.57 and 7.54) with normal electrical conductivity $(0.33$ and $0.38 \mathrm{dS} / \mathrm{m})$ during the year $2017-18$ and $2018-19$, respectively to study the response of inter and intra row spacing of sugarcane by using single eye bud settling on nutrient content, uptake and soil fertility status after harvest of sugarcane at Main Sugarcane Research Station, Navsari, Navsari Agricultural University, Gujarat, India during 2017-18 and 2018-19. On the basis of pooled analysis, significantly higher total nitrogen, phosphorus and potassium uptake at harvest recorded under planting of single eye bud settling at $120 \mathrm{~cm}$ (R2) and remained at par with planting of single eye bud settling at $135 \mathrm{~cm}$ (R3) inter row spacing. Maximum total potassium uptake at harvest noted significantly under planting of single eye bud settling at $120 \mathrm{~cm}$ inter row spacing over rest of the treatments. Significantly superior total nitrogen and phosphorus uptake at harvest obtained under planting of single eye bud settling at $60 \mathrm{~cm}(\mathrm{~S} 2)$ intra row spacing over rest of treatments. The interaction effect between different inter and intra row spacing showed that treatment combination $120 \mathrm{~cm} \times 60 \mathrm{~cm}$ (R2S2) found significantly higher total nitrogen, phosphorus and potassium uptake at harvest which remained at par with $135 \mathrm{~cm}$ x $60 \mathrm{~cm}$ (R3S2). Nutrient content in cane and trash as well as soil nutrient status after harvest of crop did not show any significant influence due to different inter and intra row spacing of sugarcane.
\end{abstract}

Keywords: Spacing, nutrient content, uptake and soil fertility status

\section{Introduction}

Sugarcane is the most important commercial crop of India and cultivated sugarcane on 4.73 million hectares area with production of 376 million tonnes of sugarcane, 32.32 million tonnes of sugar and $10.73 \%$ sugar recovery with an average productivity 79.60

t/ha during 2017-18 (Anonymous, 2019) ${ }^{[1]}$. The important sugarcane producing districts of Gujarat are Junagadh, Baroda, Namrada, Bharuch, Tapi, Surat, Navsari and Valsad. The state cultivated crop on area of 1.82 lakh hectares with production of 120.52 lakh tonnes of sugarcane and 10.67 lakh tonnes of sugar, $10.19 \%$ sugar recovery with an average productivity 66.22 t/ha during 2017-18 (Anonymous, 2019) ${ }^{[1]}$. Among different agronomic management practices, row spacing influences sugarcane productivity by maintaining adequate stalk population per unit area. Planting geometry plays an important role in water use efficiency, interception of solar radiation and evaporation. Row spacing is considered to be the most important planting geometry parameter in sugarcane. It ensures more uniform allocation of plants in an area and makes canopy of plant more efficient in intercepting radiant energy. Sugarcane yield is also affected by the spacing between the rows (Garside et al., 2009) [3]. Planting density plays an important role in the amount of solar radiation intercepted and water transpired by crop canopy which intern affects the photosynthesis and ultimately the dry matter produced and sugar extracted by sugarcane plant. Plant spacing is the critical one for providing proper nutrition, water and light to the crop plants. Hence this research serves to come up standard intra row plant spacing that can be adopted by sugarcane grower so as to attain high returns. Transplanting sugarcane settlings in wider row spacing provides more 
space and sunlight for a longer duration which increases cane productivity and also facilitates intercropping and mechanization of sugarcane agriculture from transplanting to harvesting. The maximum net returns were obtained with bud chips raised seedlings (Jain et al, 2009) ${ }^{[7]}$

South Gujarat has good potential of expanding area under sugarcane by adopting alternative planting method like sugarcane settling. One of the reasons for decline in yield is due to planting of preseason and suru sugarcane immediately after harvest of the kharif crop without proper land preparation due to time limitations. Settling planting also reduces the seed requirement by 50 to $60 \%$ than that of conventional sett planting. The other advantages are reduced water requirement during nursery stage. Progressive farmers are adopting settling planting material for sugarcane planting. However, no adequate information is so far available on inter and intra row spacing of sugarcane by using single eye bud settling in Gujarat. Keeping all these aspects in view, the present study was carried out with an objective to find out suitable inter and intra row spacing of sugarcane by using single eye bud settling for improving sugarcane productivity.

\section{Materials and Methods}

A field study was carried out at Main Sugarcane Research Station, Navsari, Navsari Agricultural University, Gujarat, India during 2017-18 and 2018-19. It comprised total sixteen treatments of four inter row spacing viz., planting of single eye bud settling at $105 \mathrm{~cm}$ row spacing (R1), at $120 \mathrm{~cm}$ row spacing (R2), at $135 \mathrm{~cm}$ row spacing $(\mathrm{R} 3)$ and at $150 \mathrm{~cm}$ row spacing (R4 ) and four intra row spacing viz., planting of single eye bud settling at $45 \mathrm{~cm}(\mathrm{~S} 1)$, at $60 \mathrm{~cm}$ intra row spacing (S2), at $75 \mathrm{~cm}$ intra row spacing (S3) and at $90 \mathrm{~cm}$ intra row spacing (S4) were evaluated in split plot design with three replications. Single eye bud settlings were transplanted as per different treatments of inter and intra row spacing. The composite soil samples from 0 to $20 \mathrm{~cm}$ depth were collected before planting and at harvest from treatment wise net plot area. Soils were air dried in shade, powdered and passed through $2 \mathrm{~mm}$ sieve and standard methods analysed for $\mathrm{pH}$ and EC (Jackson, 1979) ${ }^{[6]}$, Organic carbon (Walkley and Black, 1934) ${ }^{[17]}$, available N (Subbiah and Asija, 1956) ${ }^{[15]}$, P2O5 (Olsen, 1954) ${ }^{[10]}$ and K2O (Jackson, 1973) ${ }^{[5]}$. The plant samples were sun dried for week and oven dried at $60 \mathrm{oC}$ \pm 5 oC temperature for 24 hours. The dried samples were powdered using mixer having stainless

steel blades. The plant samples were analyzed for total $\mathrm{N}$ (Trivedi et al., 1999) ${ }^{[16]}$, P and K content (Jackson, 1979) ${ }^{[6]}$ by standard procedures. The dry matter yield and individual concentration of element were used for computing uptake. The total uptake was calculated by summation of whole cane uptake. Settlings of sugarcane variety CoN 05071 were planted in first week of December, 2017 and 2018 and harvested in the first week of December, 2018 and 2019. Recommended doses of fertilizers were applied to sugarcane (N: P2O5: K2O 250: 115: 115 kg/ha). Nitrogen was applied in four splits $(15 \%$ at planting, $30 \%$ at $6-8$ weeks after planting, $20 \%$ at $12-16$ weeks after planting and $35 \%$ at earthing up) and dose of phosphorus and potassium fertilizers (50\% at the time of planting and $50 \%$ at the time of earthing up). Data obtained from the field study was statistically analyzed by standard statistical methods by Panse and Sukhatme (1967) ${ }^{[11]}$ and Gomez and Gomez (1984) ${ }^{[4]}$.

\section{Results and Discussion \\ Effect on nutrient content and uptake Effect of inter row spacing}

It is evident from the data presented on nitrogen, phosphorus and potassium content in cane and trash at harvest (Table 1) as influenced by different inter row spacing did not exert any significant influence in pooled results. Similar results are reported by Krishnamurthy et al., (2018) ${ }^{[9]}$ and Singh et al., (2019) ${ }^{[14]}$

The perusal of data on total nitrogen $(132.54 \mathrm{~kg} / \mathrm{ha})$ and phosphorus $(37.78 \mathrm{~kg} / \mathrm{ha})$ uptake at harvest (Table 2) were significantly higher at planting of single eye bud settling at $120 \mathrm{~cm}$ (R2) and remained at par with planting of single eye bud settling at $135 \mathrm{~cm}(\mathrm{R} 3)$. Total potassium uptake at harvest $(248.69 \mathrm{~kg} / \mathrm{ha})$ was significantly maximum under planting of single eye bud settling at $120 \mathrm{~cm}$ (R2) over rest of the treatments. This might be due to higher cane yield resulted into higher uptake of nutrients. These results are in consonance with those of Jayaramudu (2012) ${ }^{[8]}$, Patel et al., (2014) ${ }^{[12]}$, Krishnamurthy et al., (2018) ${ }^{[9]}$ and Singh et al., $(2019)^{[14]}$

\section{Effect on intra row spacing}

The result revealed that nitrogen, phosphorus and potassium content in cane and trash (Table 1) did not influence due to various intra row spacing in pooled analysis. Similar findings are reported by Chaudhari (2019) ${ }^{[2]}$.

On the basis of pooled results, superior total nitrogen (147.03 $\mathrm{kg} / \mathrm{ha}$ ), phosphorus (42.23 $\mathrm{kg} / \mathrm{ha})$ and potassium (278.39 $\mathrm{kg} / \mathrm{ha}$ ) uptake at harvest (Table 2) recorded significantly under planting of single eye bud settling at $60 \mathrm{~cm}(\mathrm{~S} 2)$ over rest of the treatments. The higher uptake of nutrients resulted in higher yield of cane, indicating thereby the response to intra row spacing of $60 \mathrm{~cm}$ than $90 \mathrm{~cm}$ intra row spacing. Results are earlier reported by Raskar (2002) [13] and Chaudhari (2019) ${ }^{[2]}$.

\section{Interaction effect}

In pooled findings data, interaction effect between various inter and intra row spacing failed to express its significant effect on nitrogen, phosphorus and potassium content in cane and trash. Significantly higher total nitrogen $(167.18 \mathrm{~kg} / \mathrm{ha})$, phosphorus (48.46 kg/ha) and potassium (314.52 kg/ha) uptake at harvest (Table 2a) were reported under treatment combination $120 \mathrm{~cm} \times 60 \mathrm{~cm}$ (R2S2) which remained at par with $135 \mathrm{~cm}$ x $60 \mathrm{~cm}$ (R3S2). The difference in uptake might be due to difference in cane yield under different inter and intra row spacing. These findings are in agreement with Yadav (1984) ${ }^{[18]}$, Raskar (2002) [13], Krishnamurthy et al., (2018) ${ }^{[9]}$ and Chaudhari (2019) ${ }^{[2]}$.

\section{Effect on soil status after harvest Effect of inter row spacing}

The perusal of data (Table 3) on soil $\mathrm{pH}, \mathrm{EC}$ and organic carbon after harvest

of sugarcane revealed that various inter row spacing did not exert any significant effect during both the years. These results were in close conformity with Krishnamurthy et al., (2018) ${ }^{[9]}$. Data furnished in Table 4 showed that different inter row spacing did not affect significantly on soil available nitrogen, phosphorus and potassium after harvest of sugarcane crop during both the years. Similar results are reported by Krishnamurthy et al., (2018) ${ }^{[9]}$, Singh et al., (2019) ${ }^{[14]}$ and Chaudhari (2019) ${ }^{[2]}$. 


\section{Effect of intra row spacing}

An examination of data presented in Table 3 on soil $\mathrm{pH}, \mathrm{EC}$ and organic carbon after harvest of sugarcane revealed that various intra row spacing failed to express its significant influence during both the years. These results are in close conformity with Krishnamurthy et al., (2018) [9]. Data summarized in Table 4 revealed that different intra row spacing did not differ significantly on soil available nitrogen, phosphorus and potassium after harvest of sugarcane during both the years. Similar results are reported by Krishnamurthy et al., (2018) ${ }^{[9]}$, Singh et al., (2019) ${ }^{[14]}$ and Chaudhari (2019) [2]

\section{Interaction effect}

Interaction effect between inter and intra row spacing on soil $\mathrm{pH}, \mathrm{EC}$, organic carbon, soil available nitrogen, phosphorus and potassium $(\mathrm{kg} / \mathrm{ha})$ after harvest of sugarcane failed to get the level of significance during both the years. The results are in conformity with the findings of Krishnamurthy et al., (2018) ${ }^{[9]}$, Chaudhari (2019) ${ }^{[2]}$ and Singh et al., (2019) ${ }^{[14]}$.

Table 1: Nutrient content (\%) in cane and trash at harvest as influenced by different treatments of row and intra row spacing

\begin{tabular}{|c|c|c|c|c|c|c|}
\hline \multirow[b]{2}{*}{ Treatment } & \multicolumn{3}{|c|}{ Nutrient content $(\%)$ in cane } & \multicolumn{3}{|c|}{ Nutrient content $(\%)$ in trash } \\
\hline & \begin{tabular}{|c|}
$\begin{array}{c}\text { Nitrogen } \\
\text { content }(\%)\end{array}$ \\
\end{tabular} & \begin{tabular}{|l|} 
Phosphorus \\
content $(\%)$
\end{tabular} & $\begin{array}{c}\text { Potassium } \\
\text { content }(\%)\end{array}$ & \begin{tabular}{|c|} 
Nitrogen \\
content $(\%)$
\end{tabular} & $\begin{array}{l}\text { Phosphorus } \\
\text { content }(\%)\end{array}$ & $\begin{array}{r}\text { Potassium } \\
\text { content }(\%)\end{array}$ \\
\hline \multicolumn{7}{|c|}{ (A) Main plot factor (Inter row spacing) } \\
\hline R1: Planting of single eye bud settling at $105 \mathrm{~cm}$ & 0.234 & 0.083 & 0.525 & 0.523 & 0.073 & 0.725 \\
\hline R2: Planting of single eye bud settling at $120 \mathrm{~cm}$ & 0.232 & 0.086 & 0.505 & 0.523 & 0.074 & 0.713 \\
\hline R3: Planting of single eye bud settling at $135 \mathrm{~cm}$ & 0.232 & 0.086 & 0.504 & 0.521 & 0.074 & 0.716 \\
\hline R4: Planting of single eye bud settling at $150 \mathrm{~cm}$ & 0.236 & 0.086 & 0.510 & 0.521 & 0.072 & 0.718 \\
\hline SEm \pm & 0.001 & 0.001 & 0.005 & 0.002 & 0.001 & 0.003 \\
\hline $\mathrm{CD}(\mathrm{P}=0.05)$ & NS & NS & NS & NS & NS & NS \\
\hline $\mathrm{CV}(\%)$ & 2.72 & 5.49 & 4.91 & 2.124 & 5.512 & 1.901 \\
\hline \multicolumn{7}{|c|}{ (B) Sub plot factor (Intra row spacing) } \\
\hline S1: Planting of single eye bud settling at $45 \mathrm{~cm}$ & 0.233 & 0.085 & 0.518 & 0.518 & 0.072 & 0.720 \\
\hline S2: Planting of single eye bud settling at $60 \mathrm{~cm}$ & 0.231 & 0.086 & 0.510 & 0.521 & 0.075 & 0.716 \\
\hline S3: Planting of single eye bud settling at $75 \mathrm{~cm}$ & 0.236 & 0.086 & 0.509 & 0.524 & 0.073 & 0.719 \\
\hline S4: Planting of single eye bud settling at $90 \mathrm{~cm}$ & 0.235 & 0.085 & 0.508 & 0.524 & 0.073 & 0.716 \\
\hline SEm \pm & 0.001 & 0.001 & 0.003 & 0.002 & 0.001 & 0.002 \\
\hline $\mathrm{CD}(\mathrm{P}=0.05)$ & NS & NS & NS & NS & NS & NS \\
\hline $\mathrm{CV}(\%)$ & 2.66 & 4.49 & 2.73 & 1.816 & 6.141 & 1.143 \\
\hline \multicolumn{7}{|c|}{ Interaction (M x S) } \\
\hline SEm \pm & 0.0025 & 0.0016 & 0.0057 & 0.004 & 0.002 & 0.003 \\
\hline $\mathrm{CD}(\mathrm{P}=0.05)$ & NS & NS & NS & NS & NS & NS \\
\hline $\mathrm{CV}(\%)$ & 2.66 & 4.492 & 2.729 & 1.816 & 6.141 & 1.143 \\
\hline General mean & 0.234 & 0.085 & 0.511 & 0.522 & 0.073 & 0.718 \\
\hline
\end{tabular}

Table 2: Effect of inter and intra row spacings of sugarcane on total nutrient uptake $(\mathrm{kg} / \mathrm{ha})$ at harvest

\begin{tabular}{|c|c|c|c|}
\hline Treatment & $\begin{array}{l}\text { Total nitrogen } \\
\text { uptake (kg/ha) }\end{array}$ & $\begin{array}{c}\text { Total phosphorus } \\
\text { uptake (kg/ha) }\end{array}$ & Total potassium uptake (kg/ha) \\
\hline \multicolumn{4}{|c|}{ (A) Main plot factor (Inter row spacing) } \\
\hline R1: Planting of single eye bud settling at $105 \mathrm{~cm}$ & 107.41 & 29.60 & 206.56 \\
\hline R2: Planting of single eye bud settling at $120 \mathrm{~cm}$ & 132.54 & 37.78 & 248.69 \\
\hline R3: Planting of single eye bud settling at $135 \mathrm{~cm}$ & 121.80 & 34.85 & 228.52 \\
\hline R4: Planting of single eye bud settling at $150 \mathrm{~cm}$ & 110.90 & 31.31 & 207.63 \\
\hline SEm \pm & 3.87 & 1.14 & 5.88 \\
\hline $\mathrm{CD}(\mathrm{P}=0.05)$ & 11.94 & 3.52 & 18.13 \\
\hline $\mathrm{CV}(\%)$ & 16.06 & 16.74 & 12.93 \\
\hline \multicolumn{4}{|c|}{ (B) Sub plot factor (Intra row spacing) } \\
\hline S1: Planting of single eye bud settling at $45 \mathrm{~cm}$ & 111.18 & 31.21 & 213.08 \\
\hline S2: Planting of single eye bud settling at $60 \mathrm{~cm}$ & 147.03 & 42.23 & 278.39 \\
\hline S3: Planting of single eye bud settling at $75 \mathrm{~cm}$ & 120.76 & 34.00 & 224.88 \\
\hline S4: Planting of single eye bud settling at $90 \mathrm{~cm}$ & 93.67 & 26.09 & 175.06 \\
\hline SEm \pm & 2.75 & 0.77 & 5.39 \\
\hline $\mathrm{CD}(\mathrm{P}=0.05)$ & 7.82 & 2.19 & 15.32 \\
\hline $\mathrm{CV}(\%)$ & 11.41 & 11.29 & 11.84 \\
\hline \multicolumn{4}{|c|}{ Interaction (M x S) } \\
\hline SEm \pm & 5.50 & 1.54 & 10.78 \\
\hline $\mathrm{CD}(\mathrm{P}=0.05)$ & 15.65 & 5.90 & 30.64 \\
\hline $\mathrm{CV}(\%)$ & 11.41 & 11.29 & 11.84 \\
\hline General mean & 118.16 & 33.38 & 222.85 \\
\hline
\end{tabular}


Table 3: $\mathrm{pH}, \mathrm{EC}$ and organic carbon in soil after harvest of sugarcane as influenced by different treatments of inter and intra row spacing

\begin{tabular}{|c|c|c|c|c|c|c|}
\hline \multirow{2}{*}{ Treatment } & \multicolumn{2}{|c|}{ pH } & \multicolumn{2}{|c|}{ EC (dS/m) } & \multicolumn{2}{|c|}{ Organic carbon $(\%)$} \\
\hline & $2017-18$ & 2018-19 & 2017-18 & 2018-19 & 2017-18 & 2018-19 \\
\hline \multicolumn{7}{|c|}{ (A) Main plot factor (Row spacing) } \\
\hline R1: Planting of single eye bud settling at $105 \mathrm{~cm}$ & 7.58 & 7.56 & 0.33 & 0.34 & 0.33 & 0.35 \\
\hline R2: Planting of single eye bud settling at $120 \mathrm{~cm}$ & 7.63 & 7.65 & 0.34 & 0.35 & 0.36 & 0.36 \\
\hline R3: Planting of single eye bud settling at $135 \mathrm{~cm}$ & 7.60 & 7.64 & 0.34 & 0.35 & 0.35 & 0.35 \\
\hline R4: Planting of single eye bud settling at $150 \mathrm{~cm}$ & 7.58 & 7.62 & 0.35 & 0.36 & 0.34 & 0.34 \\
\hline SEm \pm & 0.02 & 0.03 & 0.01 & 0.01 & 0.01 & 0.01 \\
\hline $\mathrm{CD}(\mathrm{P}=0.05)$ & NS & NS & NS & NS & NS & NS \\
\hline $\mathrm{CV}(\%)$ & 1.11 & 1.39 & 7.86 & 5.57 & 8.01 & 7.45 \\
\hline \multicolumn{7}{|c|}{ (B) Sub plot factor (Intra row spacing) } \\
\hline S1: Planting of single eye bud settling at $45 \mathrm{~cm}$ & 7.56 & 7.62 & 0.34 & 0.35 & 0.33 & 0.35 \\
\hline S2: Planting of single eye bud settling at $60 \mathrm{~cm}$ & 7.64 & 7.63 & 0.34 & 0.35 & 0.35 & 0.34 \\
\hline S3: Planting of single eye bud settling at $75 \mathrm{~cm}$ & 7.63 & 7.62 & 0.33 & 0.34 & 0.36 & 0.37 \\
\hline S4: Planting of single eye bud settling at $90 \mathrm{~cm}$ & 7.57 & 7.60 & 0.35 & 0.36 & 0.34 & 0.36 \\
\hline SEm \pm & 0.04 & 0.03 & 0.01 & 0.01 & 0.01 & 0.01 \\
\hline $\mathrm{CD}(\mathrm{P}=0.05)$ & NS & NS & NS & NS & NS & NS \\
\hline $\mathrm{CV}(\%)$ & 1.63 & 1.45 & 5.20 & 5.39 & 7.67 & 9.97 \\
\hline \multicolumn{7}{|c|}{ Interaction $(\mathbf{M} \times \mathrm{S})$} \\
\hline SEm \pm & 0.07 & 0.06 & 0.01 & 0.01 & 0.02 & 0.02 \\
\hline $\mathrm{CD}(\mathrm{P}=0.05)$ & NS & NS & NS & NS & NS & NS \\
\hline $\mathrm{CV}(\%)$ & 1.63 & 1.45 & 5.20 & 5.39 & 7.67 & 9.97 \\
\hline General mean & 7.60 & 7.62 & 0.34 & 0.35 & 0.34 & 0.35 \\
\hline Initial status & 7.57 & 7.54 & 0.33 & 0.38 & 0.27 & 0.32 \\
\hline
\end{tabular}

Table 4: Available nitrogen, phosphorus and potassium in soil after harvest of sugarcane as influenced by different treatments of inter and intra row spacing

\begin{tabular}{|c|c|c|c|c|c|c|}
\hline \multirow{2}{*}{ Treatment } & \multicolumn{4}{|c|}{ Available nitrogen (kg/ha) Available phosphorus (kg/ha) } & \multicolumn{2}{|c|}{ Available potassium $(\mathrm{kg} / \mathrm{ha})$} \\
\hline & 2017-18 & 2018-19 & $2017-18$ & 2018-19 & $2017-18$ & 2018-19 \\
\hline \multicolumn{7}{|c|}{ (A) Main plot factor (Row spacing) } \\
\hline R1: Planting of single eye bud settling at $105 \mathrm{~cm}$ & 275.38 & 265.91 & 25.20 & 32.66 & 287.76 & 305.19 \\
\hline R2: Planting of single eye bud settling at $120 \mathrm{~cm}$ & 271.39 & 263.67 & 24.77 & 32.80 & 285.82 & 301.92 \\
\hline R3: Planting of single eye bud settling at $135 \mathrm{~cm}$ & 276.69 & 266.09 & 25.26 & 33.67 & 287.98 & 306.81 \\
\hline R4: Planting of single eye bud settling at $150 \mathrm{~cm}$ & 271.44 & 259.27 & 25.08 & 32.88 & 281.86 & 301.97 \\
\hline $\mathrm{SEm} \pm$ & 4.44 & 4.74 & 0.68 & 0.41 & 4.13 & 4.47 \\
\hline $\mathrm{CD}(\mathrm{P}=0.05)$ & NS & NS & NS & NS & NS & NS \\
\hline $\mathrm{CV}(\%)$ & 5.62 & 6.22 & 9.42 & 4.35 & 5.00 & 5.09 \\
\hline \multicolumn{7}{|c|}{ (B) Sub plot factor (Intra row spacing) } \\
\hline S1: Planting of single eye bud settling at $45 \mathrm{~cm}$ & 273.35 & 264.80 & 24.93 & 32.68 & 286.09 & 303.80 \\
\hline S2: Planting of single eye bud settling at $60 \mathrm{~cm}$ & 272.50 & 259.81 & 24.71 & 33.29 & 281.09 & 302.67 \\
\hline S3: Planting of single eye bud settling at $75 \mathrm{~cm}$ & 273.18 & 263.89 & 25.18 & 32.73 & 285.89 & 303.94 \\
\hline S4: Planting of single eye bud settling at $90 \mathrm{~cm}$ & 275.88 & 267.69 & 25.50 & 33.32 & 289.47 & 305.48 \\
\hline SEm \pm & 2.96 & 3.05 & 0.64 & 0.67 & 3.22 & 2.87 \\
\hline $\mathrm{CD}(\mathrm{P}=0.05)$ & NS & NS & NS & NS & NS & NS \\
\hline $\mathrm{CV}(\%)$ & 3.74 & 4.01 & 8.77 & 7.00 & 3.90 & 3.27 \\
\hline \multicolumn{7}{|c|}{ Interaction $(\mathbf{M} \times \mathrm{S})$} \\
\hline $\mathrm{SEm} \pm$ & 5.91 & 6.11 & 1.27 & 1.33 & 6.44 & 5.74 \\
\hline $\mathrm{CD}(\mathrm{P}=0.05)$ & NS & NS & NS & NS & NS & NS \\
\hline $\mathrm{CV}(\%)$ & 3.74 & 4.01 & 8.77 & 7.00 & 3.90 & 3.27 \\
\hline General mean & 273.73 & 263.92 & 25.08 & 33.00 & 285.85 & 303.97 \\
\hline Initial status & 210 & 204 & 24 & 29 & 281 & 289 \\
\hline
\end{tabular}


Table 2a: Interaction effect as influenced by different inter and intra row spacing on nutrient uptake of sugarcane

\begin{tabular}{|c|c|c|c|c|c|c|c|c|}
\hline \multirow{3}{*}{ Intra row spacing $(S)$} & \multicolumn{4}{|c|}{ Nitrogen uptake (kg/ha) } & \multicolumn{4}{|c|}{ Phosphorus uptake (kg/ha) } \\
\hline & \multicolumn{8}{|c|}{ Inter row spacing $(\mathbf{R})$} \\
\hline & $\mathbf{R 1}$ & $\mathbf{R 2}$ & $\mathbf{R 3}$ & $\mathbf{R 4}$ & R1 & $\mathbf{R 2}$ & $\mathbf{R 3}$ & R4 \\
\hline S1 & 100.23 & 120.32 & 112.37 & 111.80 & 27.90 & 33.91 & 32.08 & 30.97 \\
\hline S2 & 114.60 & 167.18 & 162.56 & 143.79 & 31.93 & 48.46 & 46.85 & 41.70 \\
\hline S3 & 104.84 & 142.32 & 125.58 & 110.29 & 28.68 & 40.73 & 35.95 & 30.63 \\
\hline S4 & 109.95 & 100.32 & 86.67 & 77.74 & 29.88 & 28.03 & 24.52 & 21.93 \\
\hline SEm \pm & \multicolumn{4}{|c|}{5.50} & \multicolumn{4}{|c|}{1.54} \\
\hline $\mathrm{CD}(\mathrm{P}=0.05)$ & \multicolumn{4}{|c|}{15.65} & \multicolumn{4}{|c|}{4.37} \\
\hline $\mathrm{CV}(\%)$ & \multicolumn{4}{|c|}{11.41} & \multicolumn{4}{|c|}{11.29} \\
\hline Intra row spacing $(\mathrm{S})$ & \multicolumn{4}{|c|}{ Potassium uptake (kg/ha) } & & & & \\
\hline S1 & 193.76 & 233.69 & 213.13 & 210.31 & & & & \\
\hline S2 & 218.59 & 314.52 & 308.69 & 271.74 & & & & \\
\hline S3 & 200.57 & 261.34 & 229.44 & 208.18 & & & & \\
\hline S4 & 211.92 & 185.21 & 162.80 & 140.30 & & & & \\
\hline SEm \pm & \multicolumn{4}{|c|}{10.75} & & & & \\
\hline $\mathrm{CD}(\mathrm{P}=0.05)$ & \multicolumn{4}{|c|}{30.56} & & & & \\
\hline $\mathrm{CV}(\%)$ & \multicolumn{4}{|c|}{11.82} & & & & \\
\hline
\end{tabular}

\section{Conclusion}

From this experimental results, it was concluded that different inter and intra row spacing failed to get the level of significance on soil $\mathrm{pH}, \mathrm{EC}$, organic carbon, soil available nitrogen, phosphorus and potassium after harvest of sugarcane during both the years. Significantly higher total nitrogen, phosphorus and potassium uptake at harvest were recorded under treatment combination $120 \mathrm{~cm}$ x $60 \mathrm{~cm}$ (R2S2) inter and intra row spacing, respectively which remained at par with $135 \mathrm{~cm}$ x $60 \mathrm{~cm}$ (R3S2).

\section{References}

1. Anonymous, Cooperative Sugar. 2019; 51(1):46-61.

2. Chaudhari NN. Effect of planting material, spacing and nitrogen management on sugarcane seed crop production under south Gujarat condition. Ph.D. thesis submitted to Navsari Agricultural University, Navsari, Gujarat, 2019.

3. Garside A, Bell M, Robotham B. Row spacing and planting density effects on the growth and yield of sugarcane. 2. Strategies for the adoption of controlled traffic. Crop and Pasture Science. 2009; 60(6):544-554.

4. Gomez KA, Gomez AA. Statistical procedure for Agricultural Research (IInd edn). An International Rice Research Institute Book, John Willey and Sons, Inc., New York, 1984.

5. Jackson ML. Soil chemical analysis. Prentice Hall of India Pvt. Ltd. New Delhi, 1973.

6. Jackson ML. Soil chemical analysis. Prentice Hall of India Pvt. Ltd., New Delhi, 1979.

7. Jain R, Solomon S, Lal P, Shrivastava AK. Nutrient application improves stubble bud sprouting under low temperature conditions in sugarcane. Sugar Tech. 2009; 11:83-85.

8. Jayaramudu M. Effect of spacing and nutrients on sugarcane for seed cane production. M.Sc. (Agri.) thesis submitted to Acharya N.G. Agricultural University, Hyderabad (Andhra Pradesh), 2012.

9. Krishnamurthy MD, Ramesh YM, Chittapur BM, Gaddi A. Effect of different establishment techniques and planting geometry on nutrient content, uptake and soil fertility status after harvest of sugarcane. International Journal of Current Microbiology and Applied Sciences. 2018; 7(10):94-102.

10. Olsen SR, Cole CV, Watanabe FS, Dean LA. Estimation of available phosphorus in soils by extraction with sodium bicarbonate. U. S. Department of Agriculture Circular, 1954, 939.

11. Panse VG, Sukhatme PV. Statistical methods for agricultural worker. Indian Council of Agricultural Research, New Delhi, India, 1967, 152-161.

12. Patel D, Raj VC, Tandel B, Patel B, Patil P, Patel AM, Patel DU. Sugarcane yield and nutrient uptake under plant geometry and variety in relation to mechanization. The Bioscan. 2014; 9(4):1445-1448.

13. Raskar BS. Response of sugarcane Co 86032 to planting materials, intra-row spacings and fertilizer levels under drip irrigation. Ph.D. thesis submitted to Mahatma Phule Krishi Vidyapeeth, Rahuri, Maharashtra, 2002.

14. Singh K, Rinwa SR, Kumar P. Influence of planting methods and nitrogen levels on nutrient uptake and soil fertility in spring planted sugarcane. International Journal of Current Microbiology and Applied Sciences. 2019; 8(10):940-946.

15. Subbiah BV, Asija GL. A rapid procedure for the determination of available nitrogen in soils. Current Science. 1956; 25:259-260.

16. Trivedi BS, Patel GG, Desai RM, Padhiyar GM. Comparison of Kjeldahal's and chromic acid methods of nitrogen determination. Gujarat Agricultural University, Research Journal. 1999; 25(1):9-14.

17. Walkley A, Black IA. Estimation of soil organic carbon by the chromic and titration method. Soil Science. 1934; 37:29-38.

18. Yadav RL. Effect of methods of planting on yield and nutrient uptake by sugarcane. Indian Journal of Agronomy. 1984; 29(3):322-326. 